\title{
EFFECT OF GIBBERELLIC ACID CONCENTRATIONS AND RUNNERS' REMOVAL RATES ON YIELD AND QUALITY OF FRIGO STRAWBERRY PLANTATIONS
}

\author{
M. E. M. Ahmed ${ }^{(1)}$, Amany A. Abd El-Latif ${ }^{(2)}$, I. A. Al-Ballat ${ }^{(1)}$ \\ and S. E. Salah ${ }^{(2)}$ \\ (1) Horticulture Department, Faculty of Agriculture, Tanta University. \\ (2) Potato and Vegtatively Propagated Crops Department, Horticulture Research Institute, \\ Agriculture Research Center.
}

Received: May 17, 2017

Accepted: Jul. 10, 2017

\begin{abstract}
This experiment was carried out at a private farm in Shoney Village, Tanta, ElGharbia Governorate, Egypt, during the two successive seasons of 2014/2015 and 2015/2016 to study the effect of runners' removal rates beside mothers full removal "no runners", five runners left, ten runners left and Without runners' removal and foliar spray of gibberellic acid 0 ppm, $25 \mathrm{ppm}$ and $50 \mathrm{ppm}$ and their interactions on vegetative growth, chemical properties, physiological traits, yield and quality of strawberry "Fortuna cv." planted under mixed planting system which fixed many runners beside mother plant with different density. Gibberellic acid $\left(G A_{3}\right)$ was sprayed three time in 30 days intervals. The experimental design was a split plot in a randomized complete block design with three replications. The result indicated that foliar application of $25 \mathrm{ppm}$ of gibberellic acid $\left(G A_{3}\right)$ with removing all runners caused an increase in plant height, size, weight and shape index of the fruits. gibberellic acid $\left(G A_{3}\right)$ at 25 ppm gave also the highest number of early fruits and early yield during both seasons, $G A_{3}$ also gave the highest value of TSS, vitamin $C$, number of leaves, number of fruits and the yield too. The study shows that it's better to use gibberellic acid $\left(G A_{3}\right)$ with $25 \mathrm{ppm}$ to spray the strawberry fruits with removing all the runners that exist beside the mother plant and that's to increase the vegetative growth and to improve the yield qualities.
\end{abstract}

Key words: Strawberry, Gibberellic acid $\left(G A_{3}\right)$, Runners, Yield, Fruit quality, Frigo.

\section{INTRODUCTION}

Strawberry (Fragaria $x$ ananassa Duch.) is an interspecific hybrid between the two species, Fragaria chiloensis and Fragaria virginiana (Darrow, 1965). Several cultivated forms of strawberry can be grouped as June bearing, overbearing and day-neutral (Hancock et al., 2005). It has traditionally been a popular delicious fruit for its flavor, taste, fresh use, freezing and processing. They are rich in ascorbic acid, secondary metabolites, simple sugars and acids (Pe'Rez et al., 1997). But are highly worsening, with soft texture, high softening rate and are highly susceptible to fungal attack (Shin et al., 2008). Carbohydrates in strawberry fruit are known to participate in many pathways related to fruit ripening, flavor development and color development (Souleyre et al., 2004). Total sugar contents of different strawberry cultivars vary, the ratio of each specific sugar to total sugars is constant (Bood and Zabetakis, 2002). Strawberry is a good source of phenolics, which function as antioxidants and are highly valued in the human diet for their role in prevention of cardiovascular disease (CVD) and cancer (Kris-Etherton et al., 2002). The production of strawberry in Egypt is $435506 \mathrm{~kg} / \mathrm{ha}$, according to (FAO, 2014).

Foliar application of gibberellic acid at 50 , $200 \mathrm{mg} / \mathrm{l}$ had increased petiole length and leaf area of the strawberry plants (Paroussi et al., 2002 a). In another study Kumar et al., (2012) showed that strawberry plants which is treated with $75 \mathrm{ppm}$ of gibberellic acid showed an increase in all vegetative growth characteristics viz., plant height, petiole length, number of leaves, plant spread and leaf area Index. Foliar application of 
strawberry plants with $\mathrm{GA}_{3}$ increased TSS and Vitamin $\mathrm{C}$ in their fruits (Sharma and singh, 2009, Kazemi et al. 2014, and Thakur et al. 2015).

Regarding the effect of foliar application of gibberellic acid on yield and its components and fruit quality, Rasheed (2010) indicated that treating strawberry with $\mathrm{GA}_{3}$ at $150 \mathrm{mg} / \mathrm{l}$ gave the longest fruits, while concentration of $300 \mathrm{mg} / \mathrm{l}$ gave the highest yield. Similar results were found by Uddin et al., (2012) who showed that $\mathrm{GA}_{3}$ at $75 \mathrm{ppm}$ gave the best growth and yield of strawberry plants.

The negative effect of $\mathrm{GA}_{3}$ at its higher concentration $(200 \mathrm{mg} / \mathrm{l})$ on total yield may be attributed to an increase in the percentage of aborted flowers and malformed fruit (nubbins), itself a consequence of the negative effect $\mathrm{GA}_{3}$ at $200 \mathrm{mg} / \mathrm{l}$ may have on pollen germination (Voyiatzis and Paroussi, 2002 a).

Number and growth of tips were higher on plants without defoliation, and decreased $44.7 \%$ on twice-defoliated mother plants. The two-defoliation management did not reduce runner tip and the dry matter mass only on plants with rooted stolons, which produced runner tips $50 \%$ heavier Defoliation of mother plants bearing rooting stolons can be used to reduce their growth, without reducing the resurrection and growth of runner tips (Picio et al., 2014).

(Klaas et al., 2009) demonstrated that keeping the runners from plants has negative effect on the total yield in the first year. On the average over three years, there is a decrease in berry weight and an increase in the amount of grade two berries. In order to obtain a high quality yield, runners must be removed during harvest.

Therefore, this study was carried out to investigate the effect of $\mathrm{GA}_{3}$ concentrations and number of runners left beside mother plants on growth yield and quality of strawberry.

\section{MATERIALS AND METHODS}

This study was conducted at a private farm in Shoney Village, Tanta, El-Gharbia Governorate, Egypt during the two successive seasons of 2014/2015 and $2015 / 2016$, to study the effect of foliar application of $\mathrm{GA}_{3}$ and runners' removal rates and their interaction on growth, yield and fruit quality of strawberry " Fragaria $x$ ananassa " var. Fortuna. Soil was clay in texture, physical and chemical properties of experimental are presented in Table (1).

Strawberry plants were planted on September $8^{\text {th }}$ and $10^{\text {th }}$ in the first and the second seasons, respectively. The experimental unit area was $12 \mathrm{~m}^{2}$. It contained 5 rows with $3 \mathrm{~m}^{2}$ in length and 80 $\mathrm{cm}$ wide. The frigo transplants were planted $25 \mathrm{~cm}$ between each other. Seedlings were transplanted in such a way that the crown dos not go much under the soil or doesn't remain in shallow. All agricultural practices for cultivation were performed as recommended by Ministry of Agriculture and land Reclamation.

Table (1): Some chemical and physical properties of the experiment soil according to Ryan et al. (1996)

\begin{tabular}{|c|c|c|c|c|c|c|c|c|c|c|c|c|c|}
\hline \multicolumn{12}{|c|}{ Chemical analysis } & \multirow{2}{*}{\multicolumn{2}{|c|}{$\begin{array}{l}\text { Physical } \\
\text { analysis }\end{array}$}} \\
\hline \multicolumn{4}{|c|}{ Cations $\left(\mathrm{meq}^{-1}\right)$} & \multicolumn{4}{|c|}{ Anions $\left(\mathrm{meq}^{-1}\right)$} & \multicolumn{3}{|c|}{$\begin{array}{c}\text { Macro } \\
\text { nutrient } \\
\text { (ppm) }\end{array}$} & \multirow{2}{*}{$\frac{\left(\mathrm{meq}^{-1}\right)}{\mathrm{Caco}_{3}^{-}}$} & & \\
\hline $\mathrm{Na}^{+}$ & $\mathrm{K}^{+}$ & $\mathrm{Mg}^{++}$ & $\mathrm{Ca}^{++}$ & $\mathrm{HcO}_{3}$ & $\mathrm{Co}_{3}^{--}$ & $\mathrm{Cl}^{-}$ & $\mathrm{So}_{4}^{-}$ & $\mathrm{N}$ & $P$ & $\mathrm{~K}$ & & $\mathrm{pH}$ & E.C \\
\hline 2.6 & 0.1 & 0.1 & 0.2 & 0.1 & --- & 1.5 & 1.4 & 80 & 45 & 640 & 1.7 & 7.8 & 0.3 \\
\hline
\end{tabular}


The experimental design was a split-plot design with 3 replications. Runners' removal rates were in the main plots 4 treatments; full removal "no runners", five runners left, ten runners left and without runners' removal and the sub plot consisted of three different concentrations of gibberellic acid (without $\mathrm{GA}_{3}, 25$ and $50 \mathrm{ppm}$ ) was sprayed after one month from transplant for three time in 30 days intervals.

\section{Data recorded \\ The following data were recorder Vegetative growth:}

Six plants were taken from each experiential plot to determine plant height $(\mathrm{cm})$ and number of leaves plant ${ }^{-1}$ at 30 days from transplant.

\section{Yield and it's components}

Fruits from six plants were harvested to determine average of weight, length and diameter of fruit at 130 days from transplant. Total number of fruits. Fruits were harvested at 130 days from transplant, when the fruit reached at harvesting stage. In harvesting period the fruits turn red in color with waxy layer. Marketable fruits were harvested at 23 day intervals during the growing season, counted, and weighed to record average fruit weight. The early yield/plant was determined as weights of all harvested fruit during the first four harvests. Total yield/ plant was calculated for all fruits harvested all one the season.

\section{Chemical constituents}

Six full mature fruits were collected randomly from each treatments in the middle of the growing season at 130 days from transplant to determine the chemical fruits quality i.e. Vitamin C $(\mathrm{mg} / 100 \mathrm{~g})$ that was determined in juice using 2, 6dichlorophenol indophenol and it was expressed as $\mathrm{mg} / 100 \mathrm{ml}$ juice as described by (A.O.A.C., 1990), and TSS (\%) was determined using a hand refractometer (abb model) and the results were expressed as brix (Cheour et al., 1991).

\section{Statistical analysis}

Data were analyzed by MSTATC computer software program adopted by Bricker, (1991) using ANOVA with the least significant difference (LSD) at the $P \leq 0.05$.

\section{RESULTS AND DISCUSSION Vegetative growth}

Form data of Table (2) it could noticed that, runner's removal rates had significant increase on the plant height and number of leaves. The highest plant and number of leaves were obtained by full removal "runners" for mother, in both seasons. And the highest plant height was recorded with five runner's left for runners, in both seasons. While, the highest of leave number was with ten runner's left or without runner's, in the season only. These trends of results are similar with (Klaas et al., 2009).

Data presented in Table (2) showed that the effects of gibberellic acid $\left(\mathrm{GA}_{3}\right)$ on vegetative growth characters, Application of $\mathrm{GA}_{3}$ at $25 \mathrm{ppm}$ had significant effect on plant height and number of leaves. Plant height for mother or runners was significantly increased, in both seasons. While, number of leaves was significantly increased in the first season for runners and in the second season for mother. The result were in accordance with Kumar et al., (2012) and Kazemi et al. (2014). Dale et al., (2008) found that may be caused by $\mathrm{GA}_{3}$, which can induce stolons formulation by activating dormant buds to grow or by preventing the flower but initiation. Waithika et al., (1978) also reported that leaf number was also increased with increasing the concentration of Gibberellic acid. This might be attributed to the fact that $\mathrm{GA}_{3}$ supply induces cell elongation and cell division Rademabher, (2000). The increase may be due to the effect $\mathrm{GA}_{3}$ promotes shoot growth by stimulating rapid cell division and elongation of plant stem and shoots Turner, (1963).

Data tabulated in Table (2) show also that, interactions between runners' removal 


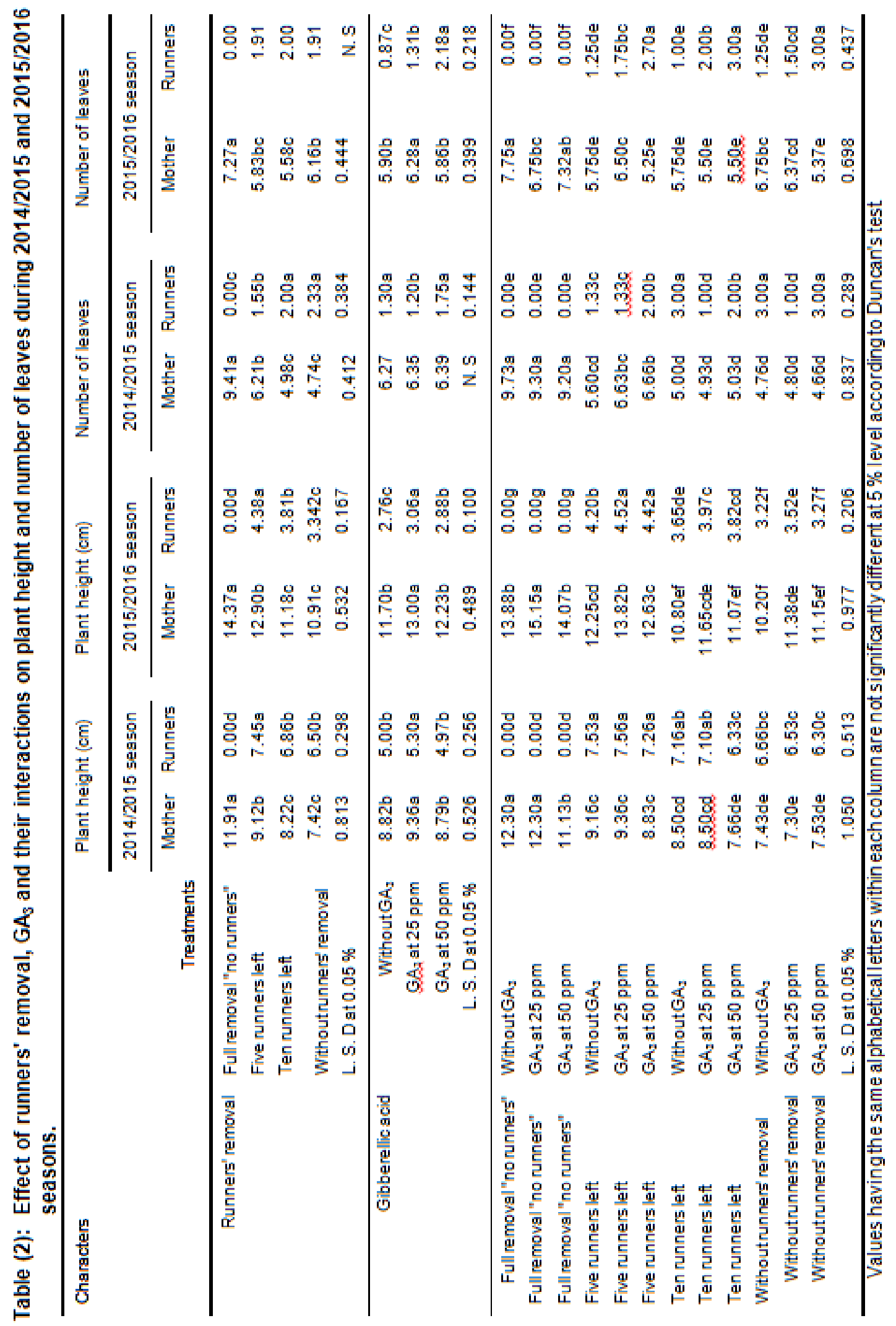


rates and foliar application of $\mathrm{GA}_{3}$ was found to be significant effect for vegetative growth for mother and runners, in both seasons. The highest values of plant height and number of leaves for mother were in treatment full removal "no runners" + without $\mathrm{GA}_{3}$ with no significant difference in treatment full removal "no runners" $+\mathrm{GA}_{3}$ at $25 \mathrm{ppm}$ in the first season. While the maximum values of plant height for runners was in treatment five runners left + with $\mathrm{GA}_{3}$ with no significant effect difference in treatments five runners left $+\mathrm{GA}_{3}$ at $25+50$ ppm, in addition to number of leaves for runners increased in treatment ten runners left + without $\mathrm{GA}_{3}$, in the first season. On the other hand the plant height and number of leaves for mother increased in treatments full removal "no runners" $+\mathrm{GA}_{3}$ at $25 \mathrm{ppm}$ and full removal "no runners" + without $\mathrm{GA}_{3}$, in the second season, respectively. And treatments five runners left $+\mathrm{GA}_{3}$ at $25+50$ ppm gave highest value on plant height for runners, in the second season. As for number of leaves for runners the maximum value was in treatment five runners left + $\mathrm{GA}_{3}$ at $+50 \mathrm{ppm}$, in the second season.

\section{Yield and it's components}

It is clear from data tabulated in Table ( 3 and 4) reflect the effects of runners' removal rates on yield and it's components for mother and runners in both seasons. Fruit volume for mother in the first season, fruit weight for the runners, fruit shape index and number of fruits in both seasons were no significant effect. While treatment ten runners left gave the highest values, fruit volume for runners in the first season, fruit volume for mother in the second season, fruit weight for mother in both seasons and fruit shape index for mother in the first season without significant difference between treatments five runners left and without runners' removal, were highly significant effect. Conversely, the maximum values were in treatment full removal' "no runners" for number of fruits and early yield for mother in both seasons, whatever total yield for mother in the first season. In addition to early and total yield for runners gave maximum value in treatment five runners left in both seasons and total yield for mother were highly significant effect in the second season. The results are in agreement Portz and Nonnecke, (2009) and Picio et al., (2014). In general among all cultivars, average berry size and total berry yield were higher when runners and flowers were removed until the end of July, mother plant weights were generally highest for Tribute. Due to smaller plants with Seascape and Albion, producers may want to plant the strawberry plants closer together, such as 6 in. to 9 in. instead of 12 in. to increase overall production within an area Portz and Nonnecke, (2009).

Data tabulated in Tables (3 and 4) showed that, there was no significant effect, fruit volume for runners in the first season and shape index for mother in the first season and the runners in the second season. While the highest values for foliar application $\mathrm{GA}_{3}$ at $25 \mathrm{ppm}$ were highly significant effect on fruit volume without significant difference between treatment without $\mathrm{GA}_{3}$, in addition to number of fruits and total yield for runners. Whatever the foliar application without $\mathrm{GA}_{3}$ were highly significant effect on fruit weight and early yield for the mother and runners in both seasons, in addition to, number of fruits and total yield for mother in both seasons. While the highest values on fruit volume for mother and runners, shape index for the mother in the second season and the runners in the first season. These results are similar with Hossan et al., (2010). $\mathrm{GA}_{3}$ stimulated rapid cell division and elongation in plant stems and shoots Turner, (1963). El-Shabasi et al., (2008) reported that $\mathrm{GA}_{3}$ application increased petiole length. Thompson and Guttride, (1959) found an increase in length and upright growth of petioles and concluded that $\mathrm{GA}_{3}$ can substitute for growth promoting substances that are produced normally under long days, the increase in size and weight with the 


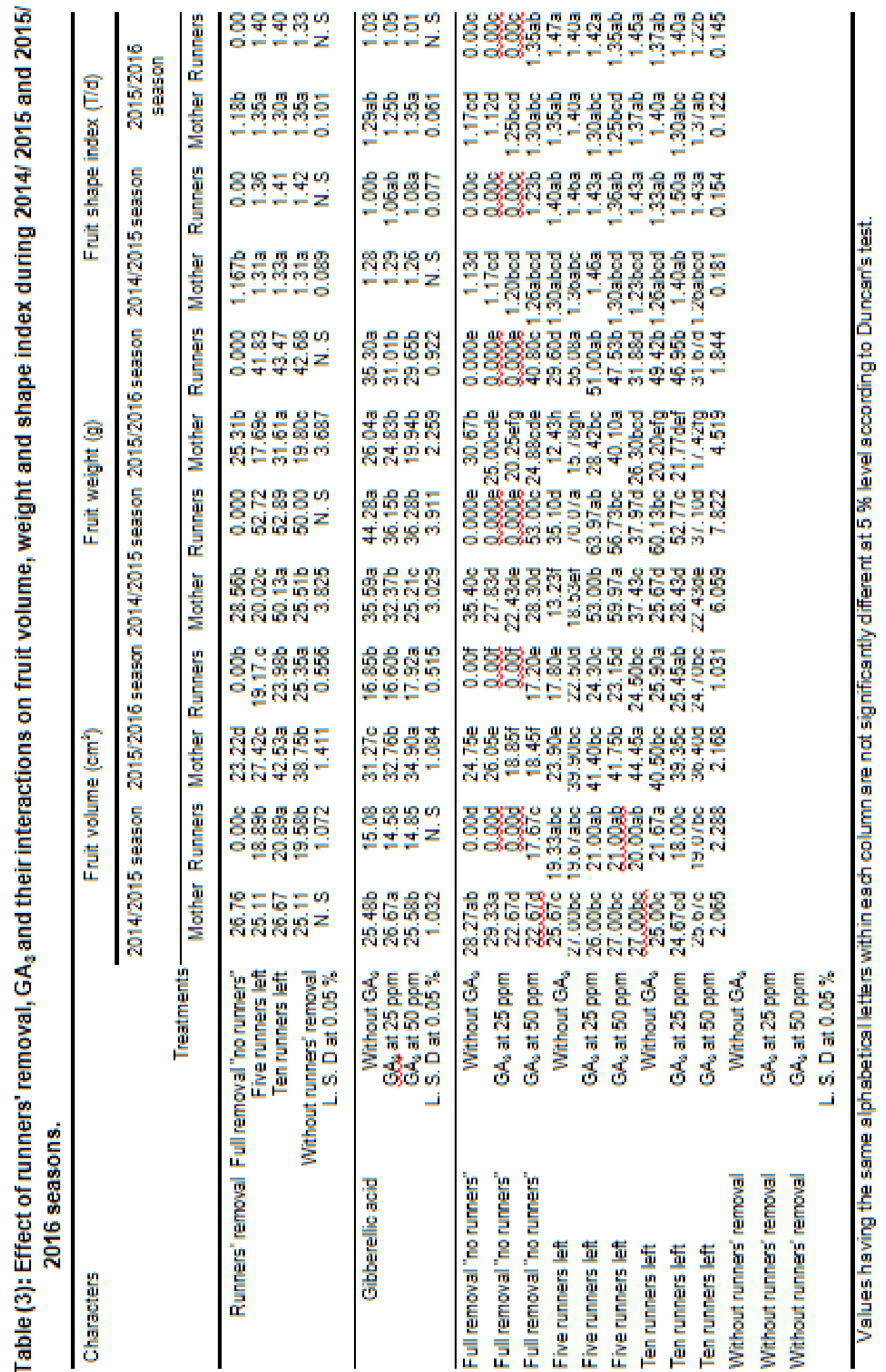




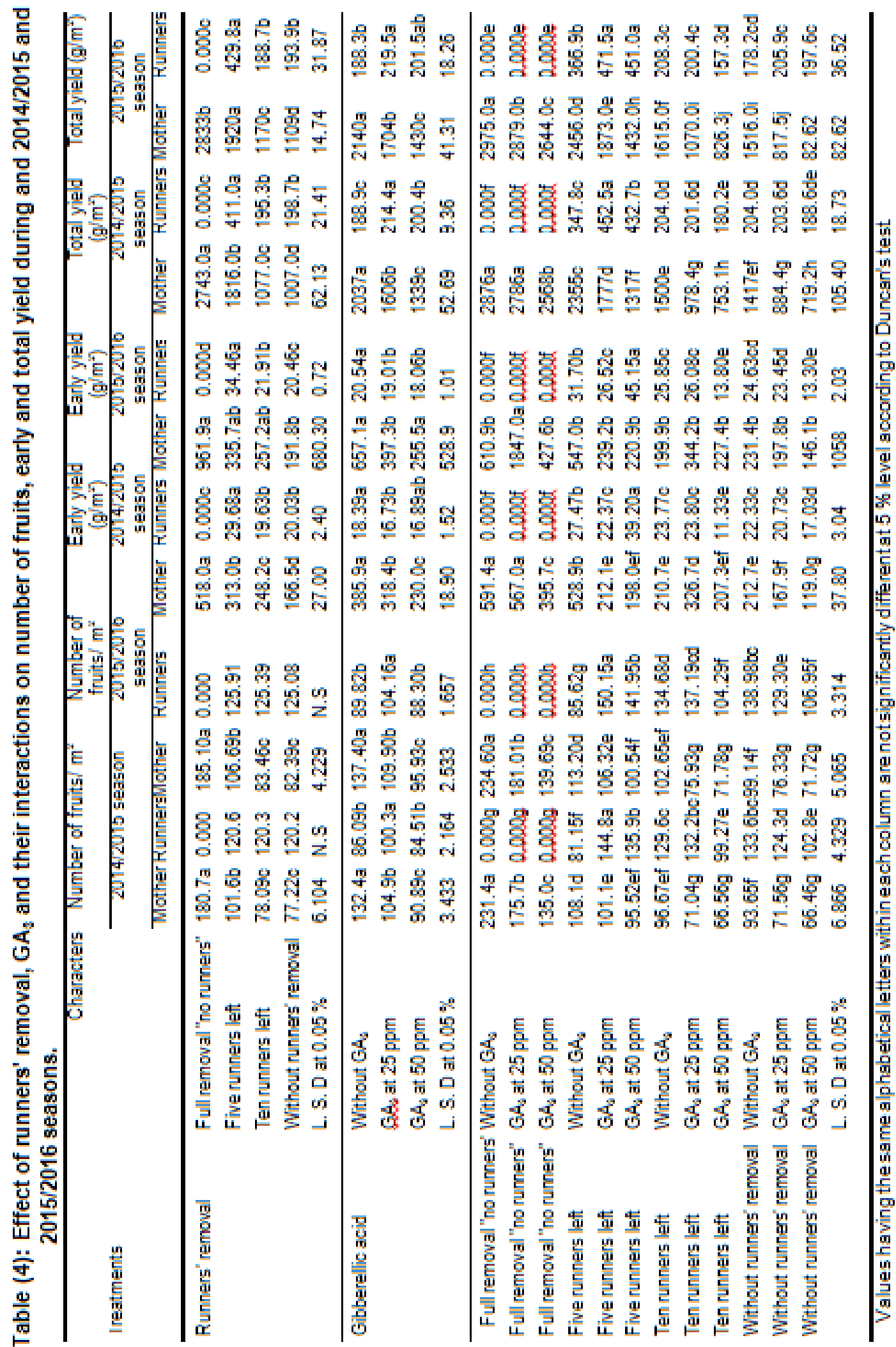


application of $\mathrm{GA}_{3}$ may be due to increased size of plant and leaf, and higher chlorophyll content which in turn may have enhanced the photosynthetic activities.

From the obtained data Table ( 3 and 4 ) it could noticed that, the interactions between runners' removal rates and foliar application of $\mathrm{GA}_{3}$. The highest values on fruit volume for mother in the first season and early yield for mother in treatment full removal "no runners" $+\mathrm{GA}_{3}$ at $25 \mathrm{ppm}$ in the second season, moreover there found highly significantly effect on fruit volume and number of fruits for runners in the second season. Number of fruits for mother in both seasons and total yield for mother in the second season in treatment full removal "no runners" + without $\mathrm{GA}_{3}$. Early yield and total yield was significant effect in treatment full removal "no runners" + without $\mathrm{GA}_{3}$ without significant difference between this treatment full removal "no runners" $+\mathrm{GA}_{3}$ at $25 \mathrm{ppm}$, in the first season. In addition to the treatment ten runners left $+\mathrm{GA}_{3}$ at $25 \mathrm{ppm}$ gave the maximum values on fruit weight for mother in both season. While fruit weight and early yield for runners was highly significant effect in treatment five runners left $+\mathrm{GA}_{3}$ at $50 \mathrm{ppm}$ in both seasons. Finally fruit weight, number of fruits and total yield for runners, in both seasons and fruit shape index for runners, in the second season was highly significant effect in treatment five runners left $+\mathrm{GA}_{3}$ at $25 \mathrm{ppm}$. While fruit shape index for mother was highly significant effect in treatment ten runners left + without $\mathrm{GA}_{3}$, in both season. In addition to fruit weight for runners was highly significant in treatment without runners' removal + without $\mathrm{GA}_{3}$, in both season. While fruit shape index for runners gave highest value in treatment without runners' removal $+\mathrm{GA}_{3}$ at $25 \mathrm{ppm}$, in the first season.

\section{Chemical constituents}

Data presented in Table (5) clearly show that the effects of runners' removal rates chemical constituents. The highest values on vitamin $C$ and TSS for mother was recorder with treatment full removal "no runners" in both seasons, in addition to for runners on vitamin $C$ it's no significant effect in both seasons. While TSS for runners was highly significant in treatment, five runners left in the first season, while the runners it's no significant in the second season. The result were accordance with Klaas et al., (2009).

It is quite clear from data in Table (5) that vitamin C content of fruit for mother and runners were significant effect with application of water in both seasons. While TSS was no significant for mother and runners in both seasons. The result are confirmed with Sharma and Singh, (2009), Ouzounidou et al., (2010), Kazemi et al., (2014) and Thakur et al., (2015). PerkinsVeazie, (1995) reported that SSC (soluble solid content) of strawberry fruits varied from $4-11 \%$ depending on cultivars and environment. The combined application of $\mathrm{GA}_{3}$ with plant growth promoting rhizobacteria can produce effects on ascorbic acid contents of strawberries and that may be due to their synergetic effect.

As for interaction between runners' removal rates and foliar application of $\mathrm{GA}_{3}$ on vitamin $C$ and TSS. When treated the mother by treatment full removal "no runners" + without $\mathrm{GA}_{3}$ on vitamin $\mathrm{C}$ and TSS was highly significant effect, in both seasons. While vitamin $C$ for runners gave highest value in treatment five runners left + without $\mathrm{GA}_{3}$, in the both seasons. In addition to TSS for runners was height significant effect in treatment five runners left $+\mathrm{GA}_{3}$ at 25 ppm. 


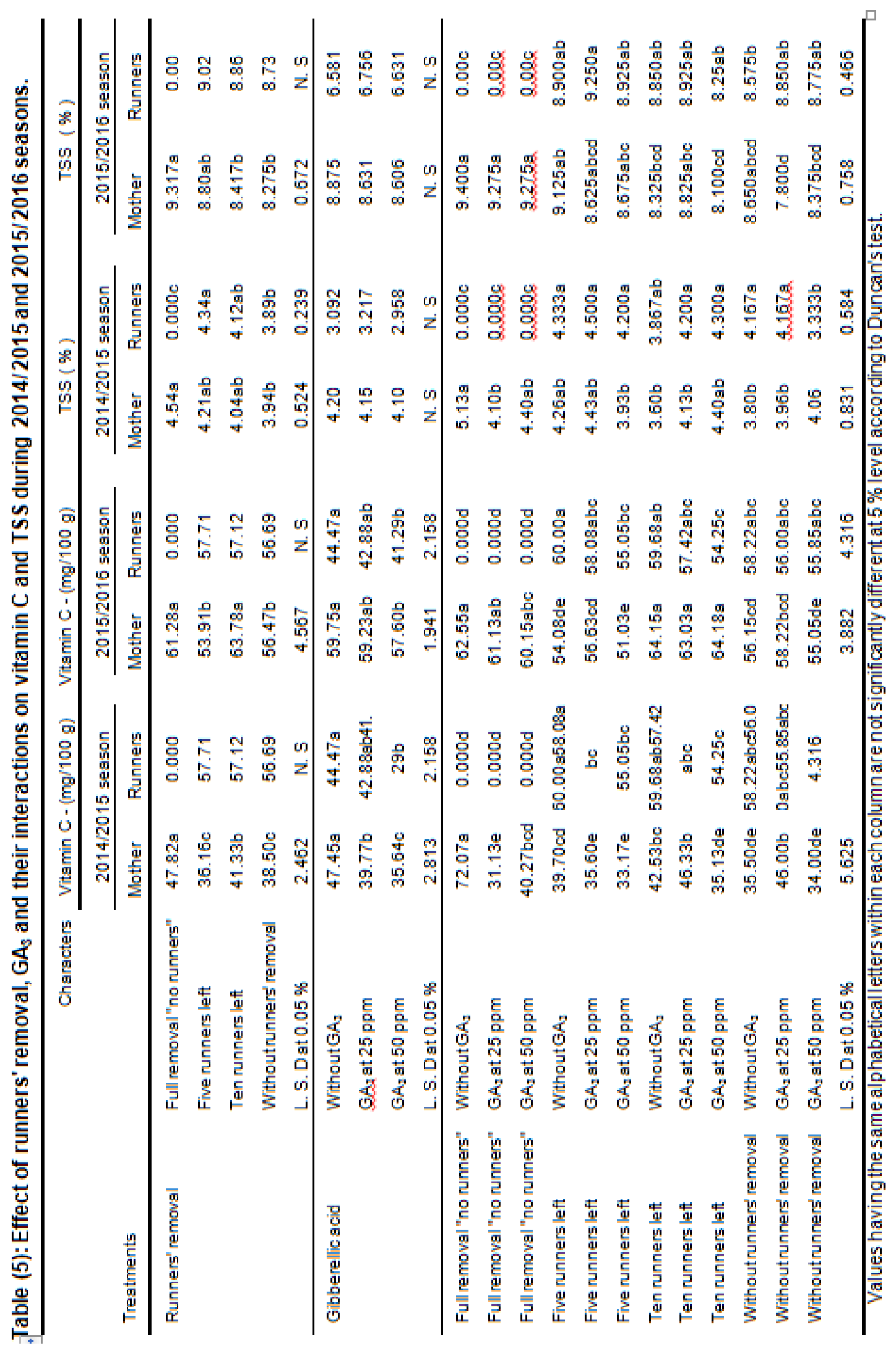




\section{REFERENCES}

A. O. A. C. (1990). Association of Official Analytical Chemists. Official methods of analysis. Hortwitz, W. (ed.), $13^{\text {th }}$ ed. Benjamin Franklin Station, Washington, D.C.: 1015 p.

Bood, K. G. and I. Zabetakis (2002). The biosynthesis of strawberry flavor, biosynthetic and molecular biology studies, Journal of Food Science 67 (1): 2-8.

Bricker, B. (1991). MSTATC: A micro computer program from the design management and analysis of agronomic research experiments. Michigan State University. USA.

Cheour, F., C. Willemot, J. Arul, D. Y. Makhlouf and Y. Desjardins (1991). Postharvest response of two strawberry cultivars to foliar application of $\mathrm{CaCl}_{2}$. Hort Science, 26 (9): 1186- 1188.

Dale, A., C. Don and K. Craig (2008). Gibberellic acid increase runner production in day neutral strawberries. Hort Sci. 31(7):1190 - 1194.

Darrow, G. M. (1965). The strawberry history breeding and physiology, 1st ed. Canada: Holt, Rinechart and Winston of Canada, Ltd; $435 \mathrm{p}$.

El-Shabasi, M. S. S., M. E. Ragab, I. I. ElOksh and Y. M. M Osman (2008). Response of strawberry plants to some growth regulators. Acta Hort. 2: 842

FAO STAT (2014). Food and Agriculture Organization. Website: <http://faostat.fao.org>.

Foda, S. A., H. H. Nassar and S. A. Monsoor (1979). Effect of some growth regulators on runner production and yield ofstrawberry. Agric. Res. Review Hort., 57: 119-125.

Garner, L, K. Grant, Z. Yusheng, K. Toan and C. Lovatt (2009). Response of evergreen perennial tree crops to gibberellic acid is crop load-dependent: GA3 increases yield and fruit size of 'Hass' avocado only in the on-crop year of an alternate bearing orchard. J. Am. Soc. Hort. Sci. 133: 3-10.
Hancock, J. F. (2005). Strawberry Growth, Development and Diseases, Cabi Publishing. Pp: 257.

Hossan, M. D. J. (2010). Response of strawberry germplasm to gibberellic acid concentrations, MSc in Horticulture, Department of Horticulture Sher. E. Bangla Agricultural University, $65 \mathrm{p}$.

Kazemi, M., Y. Researchers, E. Club and K. Branch (2014). Pre-harvest foliar application of paclobutrazol, boric acid and gibberellic acid influences vegetative growth, reproductive characteristics and quality of strawberry (Fragaria $x$ ananassa Duch. cv. Camarosa) Bull. Env. Pharmacol. Life Sci., Vol. 3 (4): 183187.

Klaas, L., K. Kahu, A. Libek and K. Hedi (2009). Effects of foliar applied fertilizers and removal of runners on the yield and berry quality of strawberry cultivar 'Polka' on Black Plastic Mulch, Sodininkystè Ir Daržininkystè., 28(4) 71-80.

Kris-Etherton, P. M., K. D. A. Bonanome, S. M. Coval, A. E. Binko-ski, K. E. Hilpert, A. E. Griel and T. D. Etherton (2002). Bioactive compounds in foods: Their role in the prevention of cardiovascular disease and cancer. Am, J Med.113: 71-88.

Kumar, R., P. Baksh, J. N. Srivastava and S. Sarvanan (2012). Influence of plant growth regulators on growth, yield and quality of strawberry (Fragaria $x$ ananassa Duch) cv. Sweet Charlie, The Asian Journal of Horticulture 7 (1): 40-43.

Paroussi, G., D. G. Voyiatzis, E. Paroussis and P. D. Drogoudi (2002a). The effect of $\mathrm{GA}_{3}$ and photoperiod regime on growth and flowering in strawberry. Acta Hort. 567:273-276.

Paroussi, G., D. G. Voyiatzis, E. Paroussis and P. D Drogoudi (2002b). Growth, flowering and yield responses to $\mathrm{GA}_{3}$ of strawberry grown under different environmental conditions. Sci Hortic. 113-96:103.

Pe'Rez, A. G., R. Olı'As, J. Espada, J. M. Olı'As and C. Sanz (1997). Rapid 
determination of sugars, nonvolatile acids, and ascorbic acid in strawberry and other fruits. Journal of Agricultural and Food Chemistry, 45: 3545-3549.

Perkins-Veazie, P. (1995). Growth and ripening of strawberry fruit. Horticultural reviews. 17: 257-297.

Picio, M. D., J. L. Andriolo, F. L. Cardoso, M. A. Lerner and J. M. Souza (2014). Defoliation of strawberry mother plants for the production of runner tips pesq. Agropec. Bras. brasília, 49(7): 515-520.

Portz, D. and G. R. Nonnecke (2009). Effect of removal of runners and flowers from day-neutral strawberries on time of harvest and total yields. lowa State Research Farm Progress Reports, Agricultural Science Commons, 9 (36) $325-328$.

Rademabher, (2000). Growth retardants: Effect on gibberellins biosynthesis and other metabolic pathway. Ann. Rev. PI. Physiol. PI. Mol. Biol., 51: 501-531.

Rasheed, H. N. (2010). Effect of gibberellic acid and benzyladenine applications on growth and yield of strawberry plant (Fragaria $\times$ ananassa Duch.), University of Baghdad, PhD thesis.

Ryan, J., S. Garabet, K. Harmsen and A. Rashid (1996). A soil and plant analysis manual. Adapted for the West Asia and North Africa Region. International Center for Agricultural Research in the Dry Areas, ICARDA, Aleppo, Syria 140 pp.

Seema, K. and K. Mehta (2015). Rhizobacteria and $\mathrm{GA}_{3}$ on plant growth, fruiting and soil health of strawberry (fragaria $x$ ananassa duch.) Cultivar chandler Parmar University of Horticulture.231, PHd.

Sharma, R. R. and R. Singh (2009). Gibberellic acid influences the production of malformed and button berries, and fruit yield and quality in strawberry (Fragaria $x$ ananassa Duch.). Scientia Hort. 119 (4):430-433.
Shin, Y., J. A. Ryu, R. H. Liu, J. F. Nock and C. B. Watkins (2008). Harvest maturity, storage temperature and relative humidity affect fruit quality, antioxidant contents and activity, and inhibition of cell proliferation of strawberry fruit. Postharvest Biol. Technol. 49, 201-209.

Souleyre, E. J. F., P. P. M. lannetta, H. A. Ross, R. D. Hancock, L. V. T. Shepherd, R. Viola, M. A. Taylor and H. V. Davies (2004). Starch metabolism in developing strawberry (Fragaria $x$ ananassa) fruits. Physiologia Plantarum, 121:369-376.

Tehranifar, A. and N. H. Battey (1997). Comparison of the effects of $\mathrm{GA}_{3}$ and chilling on vegetative vigour and fruit set in strawberry. Acta Hortic 439:627-631.

Thakur, S., K. Mehta and R. S. Sekhar (2015). Effect of $\mathrm{GA}_{3}$ and plant growth promoting rhizobacteria (pgpr) on growth, yield and fruit quality of strawberry, Fragaria $x$ ananassa Duch cv. Chandler. International Journal of Advanced Research, 3(11): $312-317$.

Thompson, P.A. and C.G. Guttride (1959). Effect of gibberellic acid on the initiation of flowers and runners in the strawberry. Nature, 184: 72-73.

Turner, J. N. (1963). Application of gibberellic acid to strawberry plants at different stages of development. Nature 197: 95-96.

Uddin, A. F., M. J. Hossan, M. S. Islam, M. K. Ahsan and H. Mehraj (2012). Strawberry growth and yield responses to gibberellic acid concentrations. J. Expt. Biosci, 3(2):51-56.

Voyiatzis, D. G. and G. Paroussi (2002). Factors affecting the quality and in vitro germination capacity of strawberry pollen. J. Hort. Sci. Biot. 77, 200-203.

Waithaka, K., B. E Struckmeyer and M. N. Dana (1978). Growth substances and growth of strawberry stolons and leaves. J. Amer. Soc. Hort. Sci. 103: 480-482. 


\section{تأثير تركيزات حمض الجبريليك ومعدلات إزالة المدادات على محصول وجودة زراعاث القرولة المبردة}

محمد السيد محمد أحمد(1) ، أمانى عطية عبداللطيف(2) ، إبراهيم الصاوى البلاط(1) ،

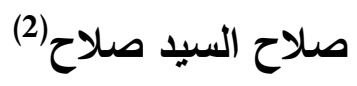

(1) قسم البساتين - كلية الزراعة - جامعة طنطا

(2) قسم البطاطس والتكاثر الخضرى - معهد بحوث البساتين - مركز البحوث الزراعية - معة طنية

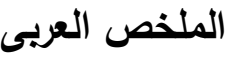

أجريت هذه الدراسة خلال موسمى 2015/1014 و 2016/2015 في مزرعة خاصة بقرية شونى - مركز طنطا محافظة الغربية لدراسة تأثير الرش الورقى بحمض الجبرلين ومعدل إزالة الددادات على النمو الخضرى والمكونات الكمبائية

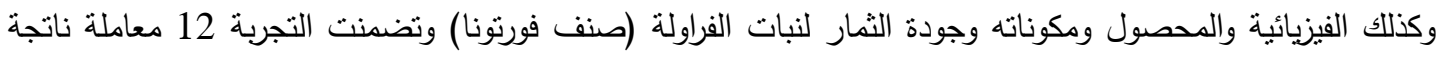

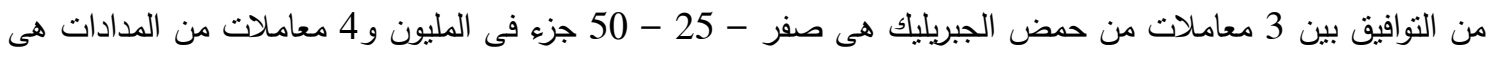
(صفر - 5مدادات - 10مدادات - ترك جميع المدادات) واستخدام تصميم القطع المنشقة لمرة واحدة. وكانت أهم النتايج المتحصل عليها هى:-

بالنسبة للرش بالجبرلين فقد أدى الرش بتركيز 25 جزء فى المليون إلى الحصول على أعلى زيادة معنويه فى عدد الثمار و المحصول المبكر خلال موسمى النمو. وبالنسبة لإزالة الددادات فقد أدى إزالة جميع المدادات إلى الحصول على أعلى لقيم المعنوية بالنسبة لصفات إرتفاع النبات و حجم و وزن وشكل الثمار . وبالنسبة للتفاعل بين إستخدام الجبرلين وإزالة الددادات أثنارت النتائج إلى أن المعاملة برش بحامض الجنات الجبريليك بتركيز

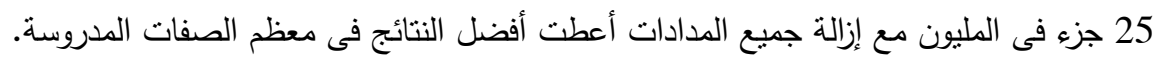

